\title{
VAYA CON DIOS, KEMOSABE: THE MULTILINGUAL SPACE OF WESTERNS FROM 1945 TO 1976
}

\author{
William F. Hanes ${ }^{1}$ \\ 1Pesquisador Autônomo, Niterói, Rio de Janeiro, Brasil
}

\begin{abstract}
Since the mythic space of the Western helped shape how Americans view themselves, as well as how the world has viewed them, the characterization of Native American, Hispanic, and Anglo interaction warrants closer scrutiny. For a corpus with substantial diachrony, every Western in the National Registry of Films produced between the end of the Second World War and the American Bicentennial (1945-1976), i.e. the cultural apex of the genre, was assessed for the presence of foreign language and interpretation, the relationship between English and social power, and change over time. The analysis showed that although English was universally the language of power, and that the social status of characters could be measured by their fluency, there was a significant presence of foreign language, principally Spanish (63\% of the films), with some form of interpretation occurring in half the films. Questions of cultural identity were associated with multilingualism and, although no diachronic pattern could be found in the distribution of foreign language, protagonism for Hispanics and Native Americans did grow over time. A spectrum of narrative/cinematic approaches to foreign language was determined that could be useful for further research on the presentation of foreigners and their language in the dramatic arts.
\end{abstract}

Keywords: Westerns, Hollywood, Multilingualism, Cold War, Revisionism

\section{VAYA CON DIOS, KEMOSABE: O ESPAÇO MULTILINGUE DE FAROESTES AMERICANOS DE 1945 A 1976}

Resumo: Considerando-se que o espaço mítico do Faroeste ajudou a dar forma ao modo como os norte-americanos veem a si mesmos, e também 
ao modo como o mundo os têm visto, a caracterização da interação entre o nativo americano, o hispânico e o anglófono é merecedora de um exame mais minucioso. Para que se obtivesse um corpus com diacronia substancial, todos os faroestes no National Registry of Films produzidos entre o fim da Segunda Guerra Mundial e o bicentenário americano (1945-1976), ou seja, o ápice cultural do gênero, foram analisados considerando-se a presença de língua estrangeira e de interpretação, as relações entre inglês e poder social, e mudanças no decorrer do tempo. A análise demonstrou que, apesar de o inglês ser universalmente a língua do poder, e de o status social dos personagens poder ser medido por sua fluência, houve presença significativa de língua estrangeira, principalmente de espanhol (em 63\% dos filmes), com alguma forma de interpretação ocorrendo em metade dos filmes. Questões de identidade cultural se mostraram associadas com o multilinguismo e, apesar de nenhum padrão diacrônico ter sido encontrado na distribuição de língua estrangeira, o protagonismo de hispânicos e de nativos americanos cresceu com o tempo. Determinou-se um espectro de abordagens narrativas/cinemáticas da língua estrangeira que poderia ser útil para futuras pesquisas sobre a apresentação de estrangeiros e de sua língua nas artes dramáticas.

Palavras-chave: Faroestes, Hollywood, Multilinguismo, Guerra Fria, Revisionismo

\section{Introduction}

Although English is the de facto rather than the de jure language of the United States, the country is generally regarded as being staunchly monolingual (if not linguistically insular), whose cultural production, particularly its film industry, has been associated with the rise of English as a global lingua franca (Crystal, 99-100). Yet in its rather brief history, most of what would become the continental U.S. has been under the $\operatorname{control}^{1}$ of non-Anglo European powers: the 1803 Louisiana Purchase from Napoleon, approximately $2,140,000 \mathrm{~km}^{2}$, nearly doubled the

\footnotetext{
${ }^{1}$ Here "control" means rights against other would-be European colonizers; all of this land was inhabited by numerous Native American tribes, while actual French or Spanish colonization/governance was limited to much smaller areas.
}

Cad. Trad., Florianópolis, v. 40, $\mathrm{n}^{0}$ 2, p. 282-321, mai-ago, 2020. 
size of the country, while the Spanish had at one time controlled more than two-thirds of the continental U.S. (from Florida to everything west of the Mississippi River). In addition to the influence of these and other languages through immigration, over 300 Native American languages were once spoken across what is now the U.S., of which 175 are still spoken (Cohen). Their influence is felt daily in a dense nationwide web of place names, e.g. the names of 26 of the 50 states are derived from Native American languages (Redish \& Lewis), which attests to a great deal of linguistic interaction. In one example, although Wyoming is derived from a Lenape word, the tribe "never actually lived in Wyoming -- it was originally the name of a town in Pennsylvania, and white settlers from that area brought the name with them when they moved west" (ibid.).

It is clear that, at least since Lewis and Clark's expedition (18041806), if not since the landing of the Mayflower, the westward arc of Anglo colonization traversed a multilingual and multicultural space that involved steady contact with and, often, dependence on, people who did not speak English. Thus, at least until consolidation of power into the hands of the federal government was complete, the West was indeed a confluence of Mexican, Native American and Anglo cultures.

The historical window of this "wild West", although illdefined, could be considered the end of the Civil War in 1865 to the completion of the transcontinental railroad (early endpoint) or to the statehood of Arizona and New Mexico, as the last pieces of the continental puzzle, in 1912 (late endpoint). After this point, the Manifest Destiny mythos was supplanted by the broadening American theatre of geopolitical involvement, first with the Spanish American War in 1898, which led to a new era of imperial exploits in the Caribbean, Central America and the Pacific, and then the shock of the Great War (1914-1918), after which "modernity" set in and tales of how the West was won were transmuted to legend. This is not to say that narratives set after this period could not be considered Westerns (e.g. Hud or 
Giant), nor that all Westerns were necessarily set in what was or would become U.S. territory (e.g. The Treasure of the Sierra Madre was set entirely in Mexico).

However, after the devastation of the Second World War, collectively revisiting these roots also appeared to become a cultural necessity, re-forging the national story ${ }^{2}$ (not only in the U.S., but in other countries, such as Japan with the rise of the Samurai epic), and thus 1950s became the golden age of the Western. In Hollywood's retelling of the history of the West, interface with the foreign other and his language had to be approached in some way, especially in the shadow of America's standoff with global Communism, growing civil rights movements, and open reassessment of America's role as global "sheriff" and "hero" during the Vietnam conflict and the arrival of its bicentennial. Thus, a three-decade time frame, 19451976 was selected for analysis.

\section{Methods}

As descriptive research (Toury), this study's purpose was to describe and find associations regarding behavior (in this case, the use of language), rather than to prescribe it. The polysystemic nature of descriptive research (Even-Zohar) requires a broad sampling technique with the diachronic reach necessary to identify and assess trends over time. However, the total corpus of Western films is, of course, dauntingly large: the American Film Institute ("The world's most comprehensive Film database") lists a total of 5177 films under the genre Western, including 20 subgenres (AFI a). Thus, despite selecting a threedecade window for study, further narrowing was necessary to produce a manageable sample.

2 The power of journalism in constructing a common national narrative (and standardizing the national language) was famously explored by Benedict Anderson, and it is clear that similar forces are at play in the cinematic narrative of "how the West was won" (i.e. retrospective nation-building).

Cad. Trad., Florianópolis, v. 40, $\mathrm{n}^{0}$ 2, p. 282-321, mai-ago, 2020. 
Although winning an Academy Award is a highly coveted and career-making milestone, a number of films that were ignored at the Oscars or even lost money at the box office have come to be considered of "cultural, historical, or aesthetic significance" (D'ooge). However, the National Film Preservation Board's National Film Registry (NFR), which is curated by the Library of Congress, implies longitudinal resonance, since induction can occur only 10 years after release. This body was established under Ronald Reagan's administration in 1988 and has, as of 2019, listed a total of 775 films. Commercial film series, such as The Criterion Collection, although consisting of critically acclaimed films, were considered to lack the broad public approval implied in the Library of Congress' NFR.

Thus, all NFR-listed Westerns produced between 1945 and 1976 were considered. Two potentially relevant NFR-listed films were excluded despite occurring in the West: Navajo Film Themselves (1966), which was a silent, anthropologically-focused anthology of short films, and Oklahoma! (1955), an adaptation of a Broadway musical in which spoken dialog would be considered of secondary importance. All of the other Westerns were watched and compared with their screenplays. All instances of non-English speech, particularly Spanish and Native American languages, were noted, as was the use of interlanguage and interpreting. Associations between language and social aspects were also considered.

\section{Results}

A total of 22 films were included and analyzed. Table 1 presents a summary of the findings, which are described below in greater detail for a selection of six films considered to involve the most significant sociolinguistic issues. 
Table 1: Multilingualism in all Westerns included in the National Film Registry

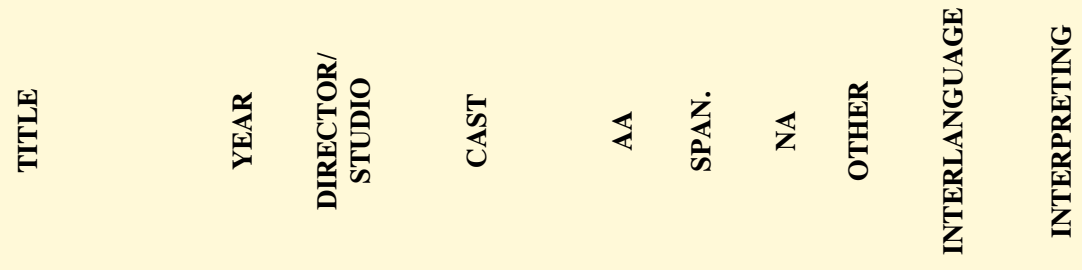

\begin{tabular}{|c|c|c|c|c|c|c|c|c|c|}
\hline $\begin{array}{l}\text { Treasure of the } \\
\text { Sierra Madre }\end{array}$ & 1948 & $\begin{array}{l}\text { Huston } \\
\text { WB }\end{array}$ & Bogart & $3 \mid 4$ & YES & --- & --- & YES & YES \\
\hline Red River & 1948 & $\begin{array}{l}\text { Hawks } \\
\text { UA }\end{array}$ & Wayne & $0 \mid 3$ & YES & --- & --- & YES & --- \\
\hline Winchester ' 73 & 1950 & $\begin{array}{l}\text { Mann } \\
\text { UNIV }\end{array}$ & Stewart & --- & YES & YES & --- & --- & YES \\
\hline High Noon & 1952 & $\begin{array}{l}\text { Zinnemann } \\
\text { UA }\end{array}$ & $\begin{array}{l}\text { Cooper } \\
\text { Kelly } \\
\text { Jurado }\end{array}$ & $4 \mid 7$ & YES & --- & --- & --- & YES \\
\hline Shane & 1953 & $\begin{array}{l}\text { Stevens } \\
\text { PARA }\end{array}$ & Ladd & $1 \mid 6$ & --- & --- & --- & --- & --- \\
\hline Giant & 1956 & $\begin{array}{l}\text { Stevens } \\
\text { WB }\end{array}$ & $\begin{array}{l}\text { Hudson } \\
\text { Taylor } \\
\text { Dean }\end{array}$ & $1 \mid 10$ & YES & --- & --- & YES & YES \\
\hline The Searchers & 1956 & $\begin{array}{l}\text { Ford } \\
\text { WB }\end{array}$ & $\begin{array}{l}\text { Wayne } \\
\text { Wood }\end{array}$ & --- & YES & YES & SV(?) & YES & YES \\
\hline 3:10 to Yuma & 1957 & $\begin{array}{l}\text { Daves } \\
\text { COL }\end{array}$ & Ford & --- & --- & --- & --- & --- & --- \\
\hline The Tall $\mathrm{T}$ & 1957 & $\begin{array}{l}\text { Boetticher } \\
\text { COL }\end{array}$ & $\begin{array}{l}\text { Scott } \\
\text { O'Sullivan }\end{array}$ & --- & --- & --- & --- & --- & --- \\
\hline Rio Bravo & 1959 & Hawks & Wayne & --- & YES & --- & --- & YES & YES \\
\hline $\begin{array}{l}\text { The Magnificent } \\
\text { Seven }\end{array}$ & 1960 & $\begin{array}{l}\text { Sturges } \\
\text { UA }\end{array}$ & $\begin{array}{l}\text { Brenner } \\
\text { McQueen } \\
\text { Bronson }\end{array}$ & --- & YES & --- & --- & YES & --- \\
\hline
\end{tabular}




\begin{tabular}{|c|c|c|c|c|c|c|c|c|c|}
\hline One-eyed Jacks & 1961 & $\begin{array}{l}\text { Brando } \\
\text { PARA }\end{array}$ & $\begin{array}{l}\text { Brando } \\
\text { Malden } \\
\text { Jurado }\end{array}$ & --- & YES & --- & $\mathrm{CN}$ & YES & --- \\
\hline $\begin{array}{l}\text { Ride the High } \\
\text { Country }\end{array}$ & 1962 & $\begin{array}{l}\text { Peckinpah } \\
\text { MGM }\end{array}$ & Scott & --- & --- & --- & $\mathrm{CN}$ & --- & --- \\
\hline $\begin{array}{l}\text { The Man Who } \\
\text { Shot Liberty } \\
\text { Valance }\end{array}$ & 1962 & $\begin{array}{l}\text { Ford } \\
\text { PARA }\end{array}$ & Stewart & $0 \mid 1$ & YES & --- & SV & YES & --- \\
\hline Hud & 1963 & $\begin{array}{l}\text { Ritt } \\
\text { PARA }\end{array}$ & Newman & $3 \mid 7$ & --- & --- & --- & --- & --- \\
\hline $\begin{array}{l}\text { Once upon a } \\
\text { time in the west }\end{array}$ & 1968 & $\begin{array}{l}\text { Leone } \\
\text { EIF \& } \\
\text { PARA }\end{array}$ & Bronson & --- & --- & --- & --- & --- & --- \\
\hline The Wild Bunch & 1969 & $\begin{array}{l}\text { Peckinpah } \\
\text { WB }\end{array}$ & $\begin{array}{l}\text { Holden } \\
\text { Borgnine }\end{array}$ & $0 \mid 2$ & YES & --- & $\begin{array}{l}\text { DE, } \\
\text { FR }\end{array}$ & YES & YES \\
\hline $\begin{array}{l}\text { Butch Cassidy } \\
\text { and the } \\
\text { Sundance Kid }\end{array}$ & 1969 & $\begin{array}{l}\text { Hill } \\
\text { FOX }\end{array}$ & $\begin{array}{l}\text { Newman } \\
\text { Redford }\end{array}$ & $4 \mid 7$ & YES & --- & --- & --- & YES \\
\hline Little Big Man & 1970 & $\begin{array}{l}\text { Penn } \\
\text { NGP }\end{array}$ & $\begin{array}{l}\text { Hoffman } \\
\text { Chief Dan } \\
\text { George }\end{array}$ & $0 \mid 1$ & --- & YES & SV & YES & YES \\
\hline $\begin{array}{l}\text { McCabe \& Mrs. } \\
\text { Miller }\end{array}$ & 1971 & $\begin{array}{l}\text { Altman } \\
\text { WB }\end{array}$ & $\begin{array}{l}\text { Beatty } \\
\text { Christie }\end{array}$ & $0 \mid 1$ & --- & --- & $\mathrm{CN}(?)$ & --- & --- \\
\hline Blazing Saddles & 1974 & $\begin{array}{l}\text { Brooks } \\
\text { WB }\end{array}$ & $\begin{array}{l}\text { Little } \\
\text { Wilder }\end{array}$ & $0 \mid 3$ & YES & --- & $\begin{array}{l}\text { DE, } \\
\text { other } \\
\text { EU }\end{array}$ & YES & YES \\
\hline $\begin{array}{l}\text { The Outlaw } \\
\text { Josey Wales }\end{array}$ & 1976 & $\begin{array}{l}\text { Eastwood } \\
\text { WB }\end{array}$ & $\begin{array}{l}\text { Eastwood } \\
\text { Chief Dan } \\
\text { George }\end{array}$ & $0 \mid 1$ & YES & YES & --- & YES & YES \\
\hline
\end{tabular}

AA = Academy Awards (Won $\mid$ Nominated); SPAN. = Spanish; NA = one or more Native American languages; WB = Warner Bros.; UA = United Artists; UNIV = Universal; PARA = Paramount; EIF = European Institute of Film; NGP = National General Pictures; $\mathrm{CN}=$ Chinese; $\mathrm{DE}=$ German; FR = French; SV = Swedish

Source: the author 


\section{Treasure of the Sierra Madre (1948)}

Figure 1: The act of interpretation in Treasure of the Sierra Madre (1948): Howard (Walter Huston, right) interpreting an elderly trader (uncredited, center) to Dobbs (Humphrey Bogart, left).

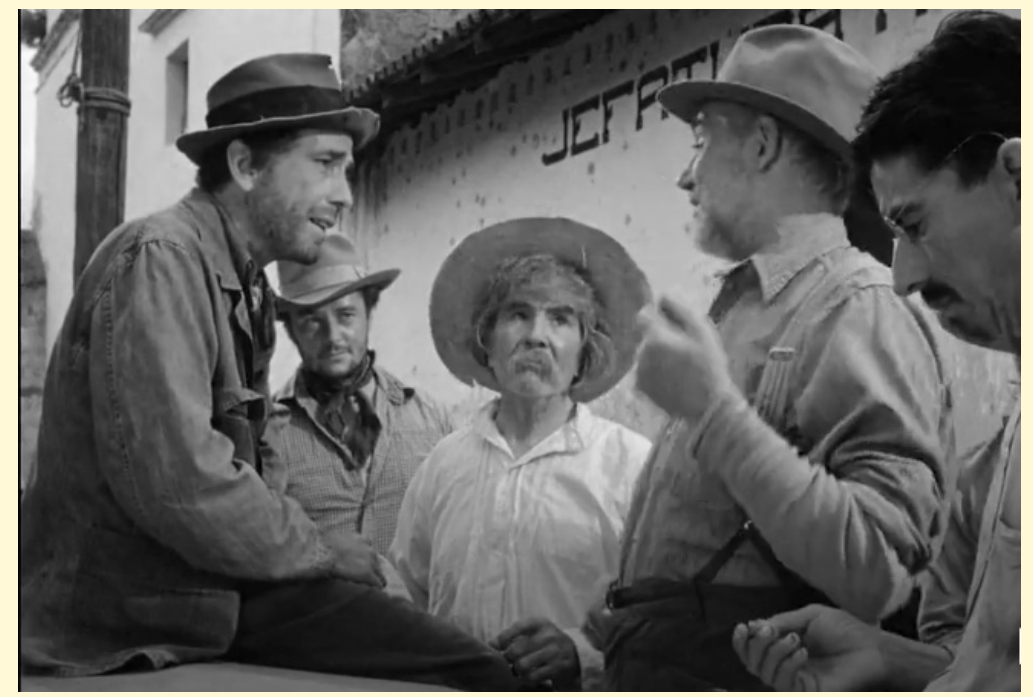

Source: Warner Brothers

John Huston's follow-up to the successful Maltese Falcon was set in Tampico, Tamaulipas, Mexico in the 1920s. The story follows down-and-out expatriates Fred Dobbs (Humphrey Bogart) and Bob Curtin (Tim Holt) as they join aging miner Howard (Walter Huston) on a gold prospecting quest deep in the wilderness of Durango state. After mining enough gold dust to set them all up for life, run-ins with a claim-jumper and bandits lead to an atmosphere of distrust, principally in Dobbs, who becomes increasingly paranoid that the others are going to rob and kill him. A group of Native Mexicans accost the men, needing help with a medical emergency, and Howard volunteers to go to their village to help, promising to 
catch up with the other two after they get back to Perla, the nearest town. Things quickly fall apart on the trail between Dobbs and Curtin, with Dobbs shooting Curtain and leaving him for dead. However, some of the Native Mexicans rescue Curtain before Dobbs comes back to finish him off, carrying him back to Howard who, having resuscitated a village boy, has been made a type of chief. Dobbs, meanwhile, making off with all the gold, is caught by the bandits, who kill him and take the donkeys into town to sell, and are themselves quickly arrested and executed. Unaware that the dust in the bags was gold, they had dumped it in the outskirts of town where it was carried away by the wind. Howard and Curtain arrive too late, but Howard enjoys the irony, planning to return to the village to live out his days in peace, while Curtain heads off to Texas to the claim-jumper's widow.

Among the first Hollywood films shot principally outside the U.S., it was also practically bilingual, featuring more foreign language than any other film in the sample. All three protagonists interact in Spanish to varying degrees, and there is extensive foreground and background dialog in Spanish throughout the film, as well as considerable interlanguage. The types of verbal interaction are described below.

Interlanguage. City-dwellers in Tampico speak to Americans in simple English peppered with Spanish. For example, an American's Mexican girlfriend is heard saying: "Why don't you and me go and buy me shopping things, huh? For instance, I could use a new pair of shoes, zapatos, and..." Her beau responds in kind: "Perdona [...] I've got business to attend to with these men. You go back up to the hotel and wait. I won't be long. Unas minutas, no más, chiquita" (Treasure of the Sierra Madre, 14:59). Ironically, the rural bandits in Durango have a city-dweller level of English proficiency, which combined with a thick accent and oafish malevolence, produce a comic effect. The chief bandit negotiates with Dobbs and crew thusly:

Look here, amigo, you got the wrong idea. We don't want to get your gun for nothing. We want to buy it. Look, I have

Cad. Trad., Florianópolis, v. 40, $\mathrm{n}^{0}$ 2, p. 282-321, mai-ago, 2020. 
a gold watch with a gold chain - made in your own country. The watch and the chain, they're worth at least 200 pesos. I'll change it for your gun. You better take it. That's a good business for you. (Treasure of the Sierra Madre, 1:08:26)

Foreign language and interpreting. Town-dwellers in Durango speak only Spanish and the Americans are forced to adapt. When the trio arrives at the town of Perla, posing as pelt hunters, they must parley with the locals about the terrain and acquire pack animals. There is an extensive discourse in Spanish by a town elder, which Howard loosely interprets for Dobbs (Figure 1). On a solo supply run on another occasion, Curtain agonizes through a list of items read in Spanish to a store clerk. It is also important to point out that when the Mexicans speak among themselves, whether bandidos or Federales, they do so exclusively in Spanish. All of this dialog passes without subtitles or interpretation - the audience is left to understand what is happening by the context; thus, they peer into the Mexicans' world rather than having the Mexicans play to an Anglophone audience. A number of Spanish loanwords are used by the protagonists in conversation among themselves, e.g. donkeys are consistently referred to as burros, bandits as bandidos, and the federal police as Federales, which further accentuates the influence of the prevailing national language and emphasizes the atmosphere of linguistic immersion.

Indigenous characterization. The group of Native Mexicans who come for Howard's medical help play a pivotal role in the narrative and are treated with a certain distinction by Huston. Although their Spanish includes no apparent grammar mistakes, they speak slowly and simply, in contrast to the cadence of Durango townsfolk or Tampico city folk. Their cultural distinctions are highlighted on a number of occasions. For example, at the initial meeting, they sit and offer their tobacco to the protagonists. Howard explains: "Take some and thank them. They're after something. Takes them a while to come to the point. To say what you want right off the bat isn't considered polite among Indians" (Treasure of the Sierra 
Madre, 1:20:40). On another occasion, their stereotypical tracking skills are pointed out; Curtin queries "How did these Indians know we were in this neck of the woods anyhow?", to which Howard replies "Don't ask me how, they just know." The line between social duty and superstition is explored when the villagers come back to retrieve Howard to show their due gratitude. He interprets: "All the saints will be angry. This is no laughing matter. I'm afraid he's determined to take us with him, even if it means by force" (Treasure of the Sierra Madre 1:26:40) Although the profound reverence they show to Howard after he resuscitates the drowned boy would, in other contexts, be patronizing, the scope of Howard's character arc, i.e. his decision to stay on and live in the village, becomes a sharp social critique, contrasting with the violence and greed of "civilization".

\section{The Searchers (1956)}

John Ford's The Searchers has been ranked by the American Film Institute as number one on its all-time top Western list (AFI b), and number 12 on its list of the greatest American movies of all time (AFI c), as well as being ranked $10^{\text {th }}$ of the 100 best movies ever made by Cahiers du Cinéma. (The Moving Arts Film Journal). It draws from real circumstances of Anglo child abduction by Native Americans and the ensuing identity crisis of the abductee, such as the case of Cynthia Ann Parker (Carlson \& Crum).

Set in "Texas 1868", Ethan Edwards (John Wayne) appears returning to his brother's homestead three years after the end of the Civil War. Soon thereafter, for unknown motives, a band of Comanches led by Scar (German-born Henry Brandon) massacre Ethan's brother and his family, kidnapping Ethan's young niece Debbie (Natalie Wood) and her teenage sister. A posse led by Texas Ranger Reverend Captain Sam Clayton sets out in pursuit, but after a casualty it breaks up, and Ethan and Martin (Ethan's adopted nephew [Jeffery Hunter]), pursue Debbie on their own. 
Arduous years later, they finally encounter Scar's encampment, being led in for a parley by Emilio (Antonio Moreno), a Mexican guide and interpreter. Scar reveals that he knows who the two are and calls in Debbie, apparently now one of his wives. After Ethan cuts the parley short, the men leave and are debating what to do, and Debbie finds them and begs them to go away. Ethan draws his pistol to kill Debbie but Martin interposes himself. She has been followed, however, and Ethan is shot in the leg. Debbie escapes and a chase and shootout ensues in which Martin successfully drives the attackers away. Too weakened for further combat, the men return home to gather a posse, which is joined by a detachment of U.S. Cavalry. The group finds and descends on the Comanche camp, Martin kills Scar and Ethan catches the fleeing Debbie, pulling her up on his saddle rather than killing her. The film closes with Ethan delivering Debbie in his arms to her neighbors, the Jorgensens, and Ethan wandering off into the horizon.

Language issues. This bleak film depicts a hierarchy in relation to English, i.e. the better the English skills, the less alien and hostile the character, though not strictly so, since Ethan and (especially) Martin border on illiteracy, and there are some treacherous and cowardly whites. Ethan's slightly nonstandard "cowboy" English is contrasted with Mrs. and Laurie Jorgensen's perfect grammar on the one hand, and the drawl of the Anglo vagabond Mose on the other. The principal categories of foreignness are described below. Substantial amounts of Spanish and Comanche were spoken. Both Ethan and Martin speak a little Spanish and Comanche, and Emilio speaks Spanish, English, and Comanche, serving as an interpreter between Ethan and Scar, who also understands English and speaks a little.

Ethan Edwards - Anglo protagonist. A Confederate soldier who never surrendered, Ethan's commitment to rescuing his niece goes far beyond that of even the famous Texas Rangers, approaching what has been described as the madness of Captain Ahab (Frankel). Ethan is an unapologetic racist, at least regarding Native Americans. His posture is revealed in several lines, such as 
the following: "...a human man rides a horse till it dies, then he goes on afoot. A Comanche comes along, gets that horse up and rides it twenty more miles. Then he eats it" (The Searchers, 39:02). He desecrates Comanche corpses as a form religious terrorism and is initially disparaging of the blue-eyed Martin for being a "halfbreed" (actually, one-eighth Cherokee), despite the fact that he originally found Martin orphaned in the wild and brought him to his brother to raise. After Debbie declares herself unwilling to go back with them (initially speaking to them in Comanche, only slowly recalling English), Ethan changes the terms of his will to make Martin the sole heir, explaining: "She's been livin' with the bucks! She's nothin' now but a..." (The Searchers, 1:33:53), i.e. having miscegenated, she is no longer fit to live; she has sided with the enemy, with anti-civilization. The irony here is heightened by the original screenplay's insinuation that Ethan believes himself to be her actual father (Nugent). Thus, cultural politics nullifies his own blood ties and elevates a collaborating "half-breed" to sonhood. Ruined by bitterness, Ethan wanes and ultimately disappears into the horizon, while Martin, 'weakened' by humaneness, abides, defeating the villain and going on (by implication) to marry, procreate and settle/colonize the land.

The Jorgensens - Northern European immigrants. This family of Scandinavian immigrants, who come to represent home to the protagonists, is distinguished from the other whites. Frank Nugent's original screenplay describes them thusly: "LARS JORGENSEN, the Edwards' neighbor, is a harried little man, Scandinavian. As we shall find out soon, he has a brisk and buxom wife and a rather astonishing brood of children" (Nugent, scene 16). This blonde brood provides suitable mates for the Edwards family (e.g. Laurie is Martin's love interest). While the children and mother (a schoolteacher) speak perfect English, Lars' English is merely functional and is spoken with a thick accent and interlanguage. The Jorgensens also represent a different, less bitter or hostile perspective than Ethan, which is clearly spelled out in this dialog: 
ETHAN: I got your boy killed.

MRS. JORGENSEN: Don't go blamin' yourself...

JORGENSEN: It's this country killed my boy! Yes, by golly!

MRS. JORGENSEN Now Lars!...It so happens we be Texicans... We took a reachin' hold, way far out, past where any man has right or reason to hold on [...] A Texican's nothin' but a human man out on a limb [...] Someday this country will be a fine good place to be...Maybe it needs our bones in the ground before that time can come. (The Searchers, 49:40)

Thus, they see themselves as having a new identity, neither their former European selves, nor even as Americans, strictly speaking, but as Texas fronteirsmen, a curious fusion. Thus, their identity is defined by the harsh land and its confluence of cultures.

The Mexicans. On the trail of Scar, Ethan and Martin wander into a cantina in "a Mexican village". Three denizens of the cantina have speaking parts. The first friendly/servile proprietor, who speaks only Spanish (the protagonists order in Spanish, and Ethan toasts in Spanish). The second is Estrella, molded on the order of Bizet's Carmen (complete with castanets and bare feet). She focuses her attention on tempting Martin, but unlike Don José, Martin escapes, albeit through Ethan's intervention. While Martin was being tempted, Ethan was negotiating with Emilio (Antonio Moreno), a local guide and interpreter, to lead him to Scar. The screenplay presents Emilio as follows: "EMILIO FIGUEROA [...] is a cynical, middle-aged, aristocratic-looking man in modified charro costume" (Nugent, scene 158). He states: "I am this man, Señor... Emilio Gabriel Fernandez y Figueroa at your service... (afterthought)... for a price... (he smiles)... Always for a price" (Nugent, scene 158b). Emilio shows sensitivity and flair as an interpreter, and reveals his code of honor after he perceives Ethan's true objective and the impending violence: he retreats, refusing to take his pay (even though he has hired a number of porters/guards to accompany the group): 
EMILIO: You understand, Señores... It is not that I am afraid...

ETHAN: Don't apologize... You got well paid...

EMILIO: ¡Madre mía! But He knows who you are -- and why you are here...This I did not know...

[He fumbles for a pouch, holds it out to Ethan.]

EMILIO: Take it. I do not want blood money. ¡Vaya con

Dios! ;Vámonos muchachos! [further Spanish dialog trailing away] (The Searchers, 1:27:40)

Thus, the Mexicans are variably portrayed as affable, mercenary to a point, or sexually aggressive. As seen above, Ethan respects Emilio for keeping up his end of the bargain, and all ends between them on reasonably good terms. Thus, bound by their European influence, Mexicans can at least be worked with, if not trusted, unlike the Native Americans.

The Comanches. Native Americans, particularly Comanches, are seen in an almost completely negative light. Scar, the antagonist, is a savage for whom the audience is encouraged to have no sympathy (Figure 2), despite the fact that his motivation was explained as revenge for the murder of his two sons. Scar speaks English and his native Comanche, although both with Tarzanic fluency:

SCAR: Two sons -- killed by white men...For each son, I take many... [looks at Emilio]

EMILIO: ....scalps.

SCAR [in Comanche]: Mayah-kay zee-eh!... [Bring the lance!] (The Searchers, 1:26:30) 
Figure 2: The Searchers (1956): the unbridled savagery of Comanche warlord Scar (played in 'redface' by Henry Brandon).

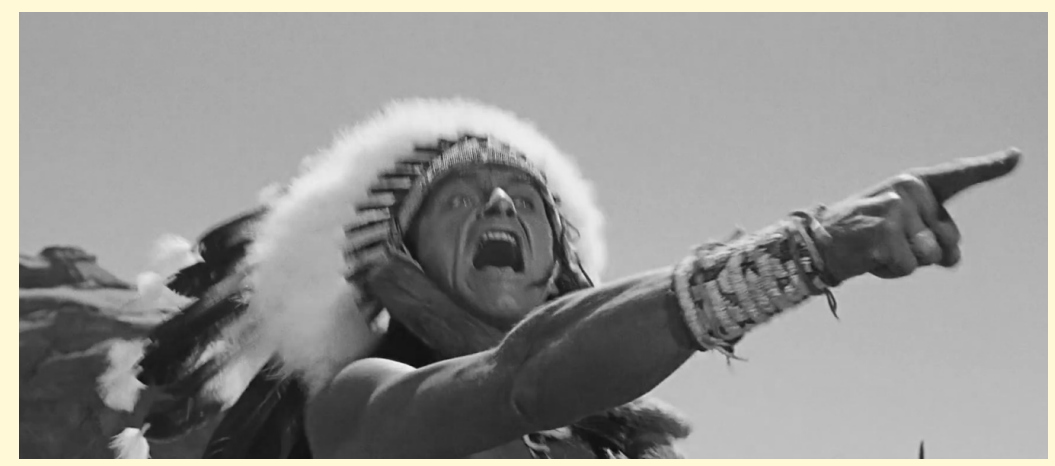

Source: Warner Brothers

Nevertheless, even he is governed by certain cultural rules, since he didn't attack Ethan and Martin during the parley in his teepee, where he could have easily overpowered them. Martin later asks: "Why didn't he make his move back there?", to which Ethan replies: "Hospitality, I guess..." (The Searchers 1:28:20). Thus, cultural constraints - the rules of engagement - ultimately cost him his life.

The other Native American character was a Comanche woman (but not from Scar's band) named Look (Beulah Archuletta), described in the original screenplay as follows: "LOOK" is somewhat under five feet tall, pigeon-toed, platter-faced and wideeyed" (Nugent, scene 131). Thinking he was trading for a blanket, Martin accidentally "acquired" Look for a couple of hats. Look dutifully follows the two on horseback and, although she speaks no English, she attempts to ingratiate herself by serving them. Ethan mercilessly heckles Martin to Martin's shame and vexation, referring to Look as "Mrs. Pauley". When Look attempts to bed down next to Martin, he kicks her away with shocking violence while Ethan "busts a gut laughing", according to the screenplay. The ridicule in this sequence is accentuated by the fact that it was 
narrated by a furious Laurie Jorgensen, who is reading a letter by Martin (her childhood sweetheart), thinking she has been jilted for a squaw. After Look begins "jabbering" in Comanche, the pair questions her about Scar, with Ethan interpreting for Martin, who attempts to conduct the interrogation in Comanche. She disappears the next morning. In a final gesture, she leaves a trail to Scar's whereabouts, although it gets lost in the snow. They later find her body among slaughtered people of Scar's band, clutching Debbie's doll. Martin closes the narrative in his letter: "What Look was doing there -- whether she'd come to warn them, or maybe to find Debbie for me...there's no way of knowing..." (The Searchers, 1:14:20). Thus, Look is depicted as ridiculous, pitiful, and enigmatic: either dutiful or treacherous.

Although the film has been described as "unflinchingly depict[ing] the terrible price that each side inflicted on the other" during the 40-year Texas-Indian wars (Nugent), Ford responded to charges of racism as follows: “The Indian didn't welcome the white man and he wasn't diplomatic [...] There was much racial prejudice in the West" (Libby, 18).

\section{Giant (1956)}

George Stevens' Giant, at over three hours in length, was a commercial and critical success, winning an Academy Award for Best Director and nominated for nine other categories, being based on the 1952 best-selling eponymous novel by Pulitzer Prize winner Edna Ferber. The story, set sometime in the late 1920s, centers on a couple: rancher Jordan "Bick" Benedict (Rock Hudson, who had played a Native American chief in Winchester '73) and his socialite wife Leslie Lynton (Elizabeth Taylor). Although the largest cattle rancher in Texas, Bick's empire is put in check by the rise of petroleum drilling, particularly by his former cowhand Jett Rink (James Dean, in his final role), As Bick slowly acquiesces to the idea of oil as a source of income, he also, at Leslie's insistence, 
slowly does an about face regarding his paternalistic racism towards his Mexican-American servants, coming to defend (in fistfights) his son Jordy's (Dennis Hopper) marriage to a Mexican-American and his mixed-race grandchild.

Language issues. Bick and his sister Luz speak (rather poor) Spanish and/or English to the servants, and Leslie is immediately receptive to using Spanish (although she doesn't seem to make much progress over the years). For example, upon the newlyweds' arrival at the train station, they are met by the servant Ángel Obregon:
ÁNGEL: ¡Bienvenida Señora! ¡Bienvenido los novios!
[Handing a bouquet of flowers to Leslie]
BICK: That means 'welcome the newlyweds'
BICK: Gracias, Ángel.
LESLIE: Oh, Gracias, Gracias, Gracias! (Giant, 20:42)

The bilingualism of the servants is revealed little by little, e.g. when Ángel's sick wife is shown replying in English to Leslie. The Benedicts debate the need for Spanish fluency to run the household and business:

LUZ: I run the house... [Leslie] don't even speak Spanish! BICK: Oh, they understand plenty of English when they want to.

LUZ: I know how to handle Mexicans. Been doin' it all my life. They'd sit on their honkers all day if I didn't keep after 'em.

BICK: Alright, Luz. Cool off! (Giant, 40:25)

As this example also shows, the Benedicts' English is far from standard - there is a pronounced difference between the speech of Luz and Jordy (a Harvard Medical School graduate), for example. 
The writers were well aware of the connection between language and social level, and the audience is meant to perceive it, as well, since in one scene the ambitious redneck Jett is reading a book entitled: How to Speak and Write Masterly English. Thus, mastery of English is flatly equated with mastery of society. Leslie's boarding-school English also either "degenerates" over time or she deliberately inflects it to fit in. The dialog continues in the same scene with the English book:

LESLIE: Jett, the other people around here - why don't they help themselves, like you done?

JETT: When you say other people, what do you mean?

LESLIE: I've just come back from [the Mexican-American village].

JETT: Buncha wetbacks! Hope you don't go getting me mixed up with none of them. I'm just as much a Texan as Bick Benedict is. I ain't no wetback!

LESLIE: But you're a workin' man...

JETT: That's somethin' I'm gonna try to fix. (Giant, $1: 23: 56)$

Four brief points will complete the description of the social order in this film: 1) Jett casts the ethicality of the Benedicts' original land acquisition into doubt; 2) Jordy's wedding took place in a Catholic, rather than a Protestant chapel (in English); 3) Ángel Obregon's son is killed in action in the Second World War, (receiving a military funeral, with an American flag being handed to his father), while Jordy is spared duty due to being in medical school; 4) Leslie's parent's keep an African-American steward, Jefferson (Napoleon Whiting), over the decades, who could be described as obsequious, professional, and apparently emotionally invested in the well-being of the family, as were the Benedicts' house servants, who prayed kneeling at Luz' wake. Thus, the parallels are drawn between the orders of the old South and Texas. 


\section{One-eyed Jacks (1961)}

The only film Marlon Brando directed (taking over after Stanley Kubrick backed out), whose initial screenplay was written by Sam Peckinpah, One-eyed Jacks tells the story of Rio/The Kid (Brando), who is betrayed by his partner in crime Dad Longworth (Karl Malden) in Sonora, Mexico in 1880. After escaping from prison five years later with fellow Mexican prisoner Chico Modesto (Larry Duran) and two more Anglo bandits they pick up along the way, they set out to Monterey, California for revenge, where Dad has gone straight and become sheriff. Upon arrival at Dad's house, Rio meets Dad's direct, restrained and self-possessed Mexican wife Maria (Katy Jurado) and his innocent and courteous stepdaughter Louisa (Pina Pellicer) (Figure 3), who sparks his interest, and he decides to hang around town, rather than immediately kill Dad and rob the local bank as his gang was planning. During a festival, he seduces Louisa and the two slip away to the beach, staying out all night and causing a great scandal in the Longworth home, apparently Rio's intent. Rio kills a man the next morning in a bar brawl while defending a flamenco dancer, and Dad takes the opportunity to publicly humiliate and violently punish him, smashing his gun hand. Rio slinks out of town, recovering at a Chinese fishing village called Punta del Diablo for several weeks until he can fire a gun. Growing restless during the wait, the gang breaks up and Rio stays behind. Unbeknownst to Rio and Chico, however, the others plan on going back to Monterey to rob the bank. When Chico protests, saying that it will ruin things for Rio in town, they kill him. The robbery is a failure: one of the men is killed and the other escapes, while a young girl is killed in the shooting. Rio, ignorant of all this, arrives in Monterey, having decided to give up on revenge and run off with Louisa, and is immediately arrested by a posse and taken to be hanged for the robbery. Rio is able to bluff his way out of his jail cell, but he is then confronted by Longworth and kills him in a shootout. As he escapes on a stolen horse, he stops to tell Louisa, now pregnant with his baby, that he will be back for her. 
Figure 3: One-eyed Jacks (1961): the earnest innocence of Louisa Longworth (left) and the astuteness of Maria Longworth (right), played by Pina Pellicer and Katy Jurado, respectively.

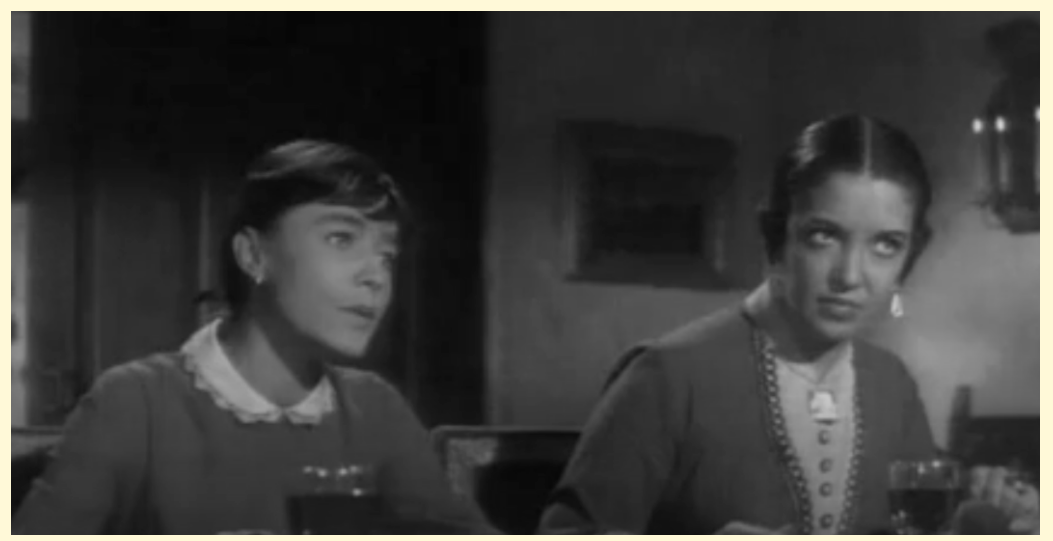

Source: Paramount

Spanish and interlanguage. The story begins with Rio and Dad robbing a bank in Mexico: the robbery is performed in Spanish and the Mexicans speak Spanish, although Rio and Dad speak English to each other. Soon after, Rio is wooing a Mexican girl, but in English: she speaks stilted, grammatical English "You may call again if you wish" (One-eyed Jacks, 6:56) but with a thick accent. The Rurales only speak Spanish. Dad negotiates in (mediocre) Spanish for horses, a protracted discussion. When the Rurales pass by soon after with their captive, Rio, discerning from the trader (all in uninterpreted Spanish) that Rio has been betrayed, the captain ridicules Rio in English: "Say, I wonder what happened to your friend, huh? Well maybe he goes back to find the shoes! ¡Jajajaja! Bueno, ya vámonos muchachos!" (One-eyed Jacks, 24:30) When Rio appears next, he has escaped from prison with Chico, and the two, chained together at the ankle (i.e. Kid \& Chico, two sides of the border), communicate in both Spanish and English; Chico has good command of English and Rio's Spanish is passable. Further 
conversations ensue in Spanish and interlanguage in the search for Dad. When Rio finally meets Dad, one of Dad's excuses for leaving is that the Mexicans "didn't talk American", and he goes on to mention "the Rurales", using the Spanish loanword rather than an English substitute. Maria and Louisa Longworth speak English, except when alone together. Louisa's English is flawed, e.g. she says to Rio upon meeting him "Do [rather than Would] you like to sit down?", while at dinner she says "...you will not be able to buy any shoe for your horse because everything will be close" (One-eyed Jacks, 42:54, 45:40). ${ }^{3}$ However, a Hispanic flower vendor in Monterey speaks perfect English to Rio. Chico is aghast at the price Rio has just spent buying the flower vendor's necklace: "Muy bonito, pero... thirty dollars?" (One-eyed Jacks, 50:04). After Louisa has been out all night with Rio, Maria interrogates her under pressure from Dad:

MARIA: Louisa, what happened? ¿Qué hiciste toda la noche? [...] ¿Qué pasó? ¿Algo? ¡Contesta! [...] ¿Louisa, es verdad? ¿Te fuiste con él?

[Louisa nods.]

MARIA: ¿Por qué, Louisa? ¿Por qué hiciste?

LOUISA: Porque yo creí que él me quería. Era mentira.

Perdóname, Mamá. Perdóname. (One-eyed Jacks, 1:10:30)

All this goes without subtitling - for a monolingual audience a significant amount of information would be lost: only by contextual clues can the discourse be followed.

Chinese. Chinese appears only briefly, as barely discernible background chatter between two men playing cards. The tiny Punta del Diablo appears to be inhabited solely by Chinese fishermen, i.e.

${ }^{3}$ Pellicer and Jurado both had successful acting careers in Mexico, and it could be that neither their accents nor Pellicer's grammar errors were feigned: Brando admitted that "...we shot that thing on the run, you know, you make up the dialogue the scene before, improvising..." (Baxter, 122).

Cad. Trad., Florianópolis, v. 40, n 2, p. 282-321, mai-ago, 2020. 
a type of ghetto, although they rent rooms and have something of a bar, i.e. they apparently receive clientele with some regularity. The proprietor understands and speaks English clearly, whereas the other residents (some little boys and an elderly man) apparently do not.

\section{Little Big Man (1970)}

Based on the eponymous novel by Thomas Berger, Arthur Penn's picaresque film depicts the life of Jack Crabb, "the sole white survivor of the Battle of Little Bighorn" (Little Big Man, 0:07), whose family was killed by Pawnee raiders. Jack, however, was found and raised by the Cheyenne (i.e. the "Human Beings") and is thus alienated from Anglo society, witnessing it through an outsider (Socratic) perspective: "I knowed General George Armstrong Custer for what he was, ... and I also knowed the Indians for what they was." (Little Big Man, 2:00) Although large portions of the story take place among the Cheyenne, only a single word of Cheyenne is heard: the screenwriter's strategy was to imply that foreign language is being used while the characters go on speaking English, i.e. a sort of built-in dubbing device:

[JACK, voiceover] But my real teacher was my adopted grandpa, Old Lodge Skins. He taught me to read a trail, Cheyenne language and lots of other things. For a boy, it was a kind of paradise. I wasn't just playing Indian, I was living Indian. Only one thing bothered me: I was small for my years. In fact, darn near a runt.

YOUNGER BEAR: The Pawnee stole seven ponies. There's going to be a war party. But you can't go. You're too little and weak, like a girl. Run away now or I'll kick you. (Little Big Man, 9:20)

Thus, they spoke Cheyenne with English words, indicated by simple, clear and concrete sentences delivered in a characteristically 
straight, almost deadpan tone. The dialog could not be considered stilted per se, e.g. Old Lodge Skins (Chief Dan George, nominated for an Academy Award for Best Supporting Actor) uses some contractions. However, there are no grammar mistakes, quite unlike Jack's English. This "dubbed" Cheyenne is also distinguished from actual English when an attacking Pawnee recognized that young Jack was white:

PAWNEE BRAVE: Little White Man...fool poor Pawnee. Big fooling. You want to eat?

[JACK, voiceover] Pawnees was always sucking up to whites.

PAWNEE BRAVE: Little White Man not mad, huh? See? Pawnee friend. Fix [i.e. kill] this bad Indian [i.e. YOUNGER BEAR] for Little White Man. (Little Big Man, $13: 31)$

At another point Jack also interprets Cheyenne for the audience: "[Little Horse] had become a heemaneh, for which there ain't no English word" (Little Big Man, 49:43). Swedish interlanguage also appears in the speech of Jack's first wife Olga, who replies $J a$ to everything and whose English is worse than the Pawnee's: "Jack, the rest, the body. You needs it." She is kidnapped by the Cheyenne, and Jack finds her again after quite some time, now the wife of Younger Bear, whom she mercilessly henpecks: "Olga never did learn much English, but she sure in hell had learned Cheyenne" (Little Big Man, 40:45, 1:08:36 ).

From a sociological perspective, the story includes a wealth of material on racial and social issues, particularly the "insanity" of the whites (personified in Custer, as a clear protest to the Vietnam War) and the demise of the Native Americans, ${ }^{4}$ that cannot be satisfactorily addressed within the scope of this paper.

${ }^{4}$ As he lays down to die, Old Lodge Skins prays: “And now, you have decided the Human Beings will soon walk a road that leads nowhere."

Cad. Trad., Florianópolis, v. 40, n 2, p. 282-321, mai-ago, 2020. 


\section{The Outlaw Josey Wales (1976)}

This film, directed by and starring Clint Eastwood, is set during and immediately after the Civil War. The wife and child of Josey, a Missouri farmer, are murdered before his eyes by Union-allied Red Legs from Kansas. Now with nothing left, he joins a gang of Confederate Bushwhackers, going to Kansas to "set things aright." When the war is over, one of his number, Fletcher (John Vernon), convinces everyone to surrender, but Josey alone refuses, and they are all massacred immediately after laying down their arms. Josey, watching from a distance, immediately wipes out most of the Union forces with their own Gatling gun before escaping, and Fletcher, a Union agent, is sent to lead a manhunt for him. While on the run, Josey accumulates, against his will, a band of misfits, including the aged Lone Watie (Chief Dan George) a kindly "renegade" Cherokee, Little Moonlight (Geraldine Keams), and Grandma Sarah (Paula Trueman) and Laura Lee (Sondra Locke), the remnants of a white Kansas family moving out to Santo Rio, Texas, whom Josey rescues from Comancheros, saving them from being traded to Ten Bears (Will Sampson), a dreaded Comanche chief. Grandma Sarah offers Josey shelter at her son Tom's ranch near Santo Rio, Texas, and Josey accepts. When they arrive in Santo Rio, however, they discover that Tom has been killed. The group, now a small community, installs itself at Tom's ranch and Josey, preferring not to fight Ten Bears, parleys and is able to come to terms with him. Soon after, however, the Red Legs posse arrives at the ranch, but Josey's crew defeat them in a shootout. Although Fletcher sees Josey in Santo Rio after the battle, he pretends not to recognize him, leading the Texas Rangers permanently off his trail as Josey rides away, bleeding, into the sunset.

Some Spanish interlanguage is spoken in Santo Rio ("Señora, please sit down"; "He went up against five pistoleros...") (The Outlaw Josey Wales, 1:33:20; 2:15:45), and the term Comanchero (for liquor/horse/women traders with the Comanche) is used, although the Comancheros are white and speak only English. 
However, a great deal of fluent Native American speech can be heard, principally between Moonlight, a Navajo who does not speak (but understands) English and Watie, who can communicate with her and interprets her to Josey. She, in fact, is so talkative that Josey grumbles to Watie "Hell, man, can't you get her to shut up?" (The Outlaw Josey Wales, 1:00:10).

Figure 4: The Outlaw Josey Wales (1976): peace talks with Comanche leader Ten Bears (Will Sampson). The blue war paint heightens the character's cultural alterity.

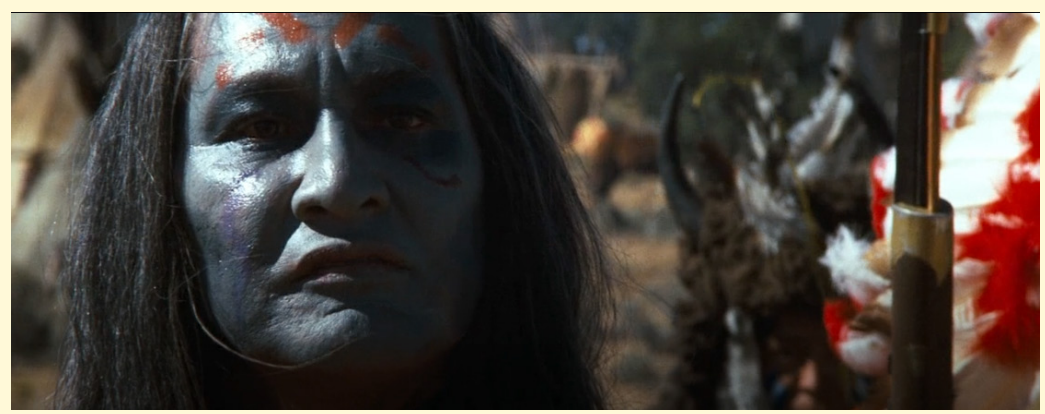

Source: Warner Brothers

Native American characters. It is important to point out that Lone Watie speaks flawless English and carries himself on equal par with Wales (except for being elderly and having lost "his powers"); he is neither a subordinate or a dependent, but their relationship of mutual respect plays out in laconic, jocular banter. This is the only such relationship found in the sample, except for the fatherly respect between Jack Crabb and Old Lodge Skins (also played by Chief Dan George) in Little Big Man and Rio and Chico's friendship in One-eyed Jacks. Watie holds his own against disrespectful whites, for example in an exchange with a carpetbagger selling 'snake oil': 
CARPETBAGGER: Say, you're an Indian, aren't you? You speak any English?

[WATIE nods]

CARPETBAGGER: Well, sir, this is the very best thing... for those who can't handle their liquor.

WATIE: What's in it?

CARPETBAGGER: I don't know. Various things. I'm only the salesman.

WATIE: You drink it.

CARPETBAGGER: What?

WATIE: You drink it. [Walks away]

CARPETBAGGER [turning to crowd]: Well, what can you expect from a nonbeliever? (The Outlaw Josey Wales, 1:50:06)

Little Moonlight, who was frequently beaten by her previous "owner", a white liquor salesman, was about to be raped in his unmoved presence when Josey arrived and shot up the place. With a binding sense of duty, she feels she belongs to Josey (presumably willing to become his wife), but Josey roundly rejects this idea (in part) on moral grounds: "I don't want nobody belongin' to me." Josey later becomes involved with the blonde Kansan Lorna Lee, who bears more resemblance to his deceased wife, after which Moonlight engages in a winter-spring romance with Watie. Chief Ten Bears has also had regular contact with whites. According to one of the Santo Rio townsfolk: "Each year, [Ten Bears] has met with one of your bluecoat generals [...] General Sherman has come with more promises. But Ten Bears will move no more" (The Outlaw Josey Wales, 1:37:11). In an extended parley with Josey, Ten Bears, a commanding presence of alterity whose ineffable expression is heightened by powdery blue war paint (Figure 4), speaks concrete grammatical English, concluding:

There is iron in your words of death for all Comanches to see. And so there is iron in your words of life. No signed paper can hold the iron. It must come from men. The words 
of Ten Bears carry the same iron of life and death. It is good that warriors such as we meet in the struggle of life... or death. It shall be life. So will it be. (The Outlaw Josey Wales, 1:50:30)

Results - summary. Of the 22 films included in the sample, 13 (59\%) were nominated for an Academy Award and six won at least one (four of which included a language other than English); the sample also included seven of the American Film Institute's top 10 Westerns.

Spanish was spoken in $14(63 \%)$ of the films, in some to a significant degree (e.g. Treasure of the Sierra Madre, Giant): at times it was interpreted, although at other times not, while sometimes it appeared as interlanguage. The appearance of Spanish followed no discernible pattern over these three decades.

Native American languages appeared in four (18\%) films, again, sometimes interpreted, sometimes not, although it should be pointed out that of nine total characters who spoke proper lines (and not background chatter, war whooping, etc.) in these languages, only four were native speakers (i.e. not whites in "redface" or assimilated whites, such as Jack Crabb in Little Big Man or Debbie Edwards in The Searchers). Thus, only in two films, The Searchers and The Outlaw Josey Wales, did actual Native Americans speak their own languages.

Chinese was spoken in three (13\%) films, but only as background chatter. The only significant Chinese character, Bert in Rio Bravo, spoke grammatical but stilted English. Other foreign languages appeared in four films, principally Swedish ("Scandinavian") as interlanguage. The earliest film in which a language other than Spanish or Native American appeared was One-eyed Jacks (1961Chinese), and of the 11 films produced from 1961-1976, seven used a language other than Spanish or Native American, although mostly as background or interjections: none of it was especially critical to the plot.

Significantly, acts of interpretation occurred in 11 films, $50 \%$ of the sample, and they were occasionally critical to the plot, even 
a matter of life and death (e.g. The Searchers and Treasure of the Sierra Madre).

\section{Discussion}

Approaches to foreign language. In this sample of 22 films over three decades, six different approaches were found regarding the presentation of foreign language and otherness. The first could be called "deformed English", which is to say non-native speech characterized by ungrammaticality, which typically involves rudimentary, simplistic discourse (e.g. a lack of abstract thought), a heavy foreign accent or both. This is the language of Tarzan or the Lone Ranger's sidekick Tonto.. Although these two characters were in fact protagonists, this type of discourse is generally reserved for subalterns; their alienation from the rules of "polite society" is manifested by breaking the rules of the language. Perfect examples would be the speech of the Pawnee warrior in Little Big Man or the Cherokee cowhand Quo in Red River. Heavy accents, however, (even including some grammar errors) were not necessarily associated with weak-mindedness, exemplified by the dignified Maria and Louisa Longworth in Oneeyed Jacks or by Helen Ramirez in High Noon. A corollary, rather than a subset, of this type is the grammatical English discourse of Native Americans, particularly when played by Native Americans, for example characters such as Ten Bears and Lone Watie in The Outlaw Josey Wales and various characters in Little Big Man (e.g. Old Lodge Skins and Sunshine). The flat, deadpan delivery of short, uncomplicated (jargon-free) sentences that include the use of concrete metaphorical language (Old Lodge Skins repeats "My

\footnotetext{
${ }^{5}$ It should be pointed out that English grammar could also be degraded in native speakers, signifying lower social standing: Walter Brennan's Stumpy in Rio Bravo and Groot in Red River, were subservient and fairly impotent 'old coots' who speak with typical hillbilly pronunciation and grammar.
}

Cad. Trad., Florianópolis, v. 40, n 2, p. 282-321, mai-ago, 2020. 
heart soars like a hawk") produces a feeling of alterity without discernible accent or error, a separate mind within the language.

However, the next step up the grammatical ladder, interlanguage, generally signified a step down in character, not towards barbarism, but buffoonery. This approach involved characters who spoke sufficiently fluent English but pidginized it with foreign words. This was used especially, but not exclusively, for Mexicans, most clearly exemplified by Carlos Robante, the henpecked hotel owner in Rio Bravo. However, this strategy was also consistently used to mark Scandinavian immigrants, answering in the affirmative with "Ja, Ja". Foreign exclamations (such as "Ay Chihuahua!") had to be understandable to maintain the comic effect for mainstream Anglophone audiences, which is demonstrated by the fact that no Native American or Chinese interlanguage was found in the sample. That being said, not all interlanguage characters were objects of ridicule; Chico in One-eyed Jacks, for example, who spoke Spanish to Mexicans, used some Spanish expressions in his English dialog (often for a comic effect), but with a self-possessed intentionality, seemingly more indicative of pride in his own culture than incomplete assimilation to Anglo society.

In a reversal of interlanguage, an alternative strategy was to have monolingual foreigners speak in English, which was accomplished in two ways: as an announced strategy or as irrational "movie magic". Little Big Man employed the former type: since the bulk of the film took place among the Cheyenne, rather than use extensive subtitling (which may have alienated audiences in 1970), Jack Crabb simply announced in voiceover that Old Lodge Skins taught him the Cheyenne language, while the characters immediately continued on in English, although the discourse suggested that the characters were, to some degree, speaking Cheyenne with English words. On the other hand, suspending logic, in The Magnificent Seven rural peasants, whom it would be reasonable to assume were monolingual Spanish speakers, spoke English to the heroes, to each other, and to Mexican bandits when no gringos were present, a phenomenon that was simply left unexplained. The Wild Bunch 
also included some Mexican villagers whose English fluency also stretched credulity, although Spanish was spoken in the background, while Mexicans in an actual town spoke little or no English.

This should be contrasted with what we will call immersion, typified by Treasure of the Sierra Madre. In this film a more realistic approach to foreign language is taken: without resorting to subtitles, rural Mexicans speak only Spanish and city dwellers speak English interlanguage when necessary. The audience is left to decipher significant amounts of uninterpreted Spanish dialog, although Walter Huston's Howard interprets in situations of vital importance. Thus, Anglophone audiences participate in the American characters' alienation south of the border. Although to a lesser degree, this approach was also used in Butch Cassidy and the Sundance Kid while the duo were operating in Bolivia, and more or less similar constraints appeared in Giant due to the large number of Spanish speakers (principally background characters), who, nevertheless, were sufficiently conversant in English when necessary.

Other films backgrounded foreign language as faintly overheard chatter. This strategy was used to briefly indicate the presence of Chinese among arriving passengers in McCabe \& Mrs. Miller, in a fishing village in One-eyed Jacks, and in a mining camp in Ride the High Country. As background noise, audiences could get a taste of the multilingual atmosphere without it interfering in the foregrounded English language narrative.

Another strategy was suggesting foreign language, which occurred in two distinct ways. In High Noon, a single brief exchange in Spanish between Helen Ramirez and Marshall Kane: "HELEN: Un año sin verte; KANE: Sí, lo sei. Goodbye Helen" (High Noon, 31:40). subtly indicates that their erstwhile interracial romance was also multilingual; thus, in this case Spanish was backgrounded into the past. However, dialog in a foreign language was seen but audibly blanked out by a musical interlude in Butch Cassidy and the Sundance Kid (during a bank robbery), and by voiceover narration in The Searchers (as Martin trades for Look with the Cheyenne). 
It should be pointed out that overlapping or even conflicting strategies were found in the same film: in The Wild Bunch, for example, both domestication and foreignization (Venuti 6,24) were used, the former with rural villagers and the latter with towndwellers in Agua Verde, while The Searchers involved a number of different strategies.

Good guys speak Mexican? English clearly dominated as the language of power, a "hypercentral" language in this system (Swaan), not so much by ignoring other languages, but through contrast or, rather, competition. A multilingual space was described more often than not, but other languages were depicted in the mouths of peripheral, dependent characters, i.e. people who lost the West (it's not a contest if there are no contenders). Clear examples of this include Look (and even Debbie) in The Searchers and Moonshine in The Outlaw Josey Wales. Manly (undomesticated) adversaries maintained their dignity to a certain extent by conforming to English as the lingua franca of parley, i.e. "in situations characterized as officielle" and authoritative (Bourdieu (a), 45): exemplified by Ten Bears in The Outlaw Josey Wales, Scar in The Searchers, and General Mapeche in The Wild Bunch. Thus, the multilingual space described herein could be more clearly as a field (i.e. of battle) according to Bourdieu's terminology:

\begin{abstract}
[...] a structured social space [...][that] contains people who dominate and others who are dominated. Constant permanent relationships of inequality operate inside this space, which at the same time becomes a space in which the various actors struggle for the transformation or preservation of the field ((b), 40).
\end{abstract}

On the other hand, willingness to enter (at least somewhat) into the culture and language of the other was also associated with heroism/ nobility, as seen in Treasure of the Sierra Madre, One-eyed Jacks, The Wild Bunch, The Magnificent Seven, and Giant, while the opposite - 
racism/jingoism (e.g. Humphrey Bogart's Dobbs in Treasure of the Sierra Madre or James Dean's Jett in Giant) - was associated with villainy, although not always, since John Wayne's Ethan Edwards in The Searchers was a vehement racist against Native Americans yet spoke Comanche and understood certain cultural subtleties, and Karl Malden's Dad Longworth in One-eyed Jacks married a Mexican and adopted her daughter, although he was belligerent and domineering to them when his authority or character were challenged. It is important to point out that multilingualism was practically a given, a necessity, for non-native English characters, rendering upward mobility rather than honor. The subtext in these films is that when Anglos deigned to learn a foreign language, it was a type of charity, even if they were constrained to do so by circumstances.

However, a bicultural identity, as a step beyond bi- or multilingualism, was also depicted as having a price tag: alienation - an ultimate decision about tribal loyalty, particularly with regard to choosing a mate, a theme as old as Othello. Although Jack Crabb in Little Big Man would be the epitome of this phenomenon (and Jordy in Giant underwent similar turmoil through his biracial marriage), the "one-eighth Cherokee" Martin (in The Searchers) strove tremendously to save innocent white Debbie from the wild Comanche Scar and assimilate through marriage to Laurie Jorgensen, a Scandinavian immigrant's daughter (eschewing his accidental Comanche bride, and having been 'rescued' by Ethan from the clutches of a man-eating Mexican barmaid). On the other hand, the Mexican Maria Longworth (in One-eyed Jacks) sided with her daughter rather than her white husband, lying to protect her, while Josey Wales refused the Navajo Moonlight as a bride, passing her along, so to speak, to the Cherokee Lone Watie.

\section{Final Remarks}

Despite the common-sense perception of a monolingual Hollywood, particularly in the golden age of that most American 
of genres and during the most patriotic of times, the question of language is more complex, and perhaps less innocent, than one of simple ignorance or denial. Although avoided or downplayed in a number of films, including Shane (1953), 3:10 to Yuma (1957), The Tall T (1957), Ride the High Country (1962), and even Sergio Leone's Once Upon a Time in the West (1968), this sample of prestigious films shows that the world of the Western is a history of race and power relations, which necessarily involve, if not hinge upon, matters of speech and discourse. The writers and directors ascribed potency and moral right through language according to their intentions and biases, which were promoted (and steered to some degree) by the studios, ratified (or censured) by the critics, and approved and perhaps regarded as legitimate models of reality by the audience (which, it must be noted, was - and remains - a global audience) ${ }^{6}$

In these films, language (i.e. dominance of English) was central to power and protagonism, as well as the reverse: the degree of alienation to (proper) English was directly associated with irrelevance, a theme dating back, at least, to Shaw's Pygmalion, and one that has been identified in other languages (Hanes, 172). However, the willingness of Anglo characters to learn other cultures and languages was associated with nobility, while racism was associated with villainy, although not always. The act of interpretation was frequent and often depicted as vital.

A spectrum of different strategies (that did not progress in any certain direction over time) was employed to portray foreign language and foreignness: deformed English, interlanguage, having monolingual foreigners speak in English (either as an announced device or as "narrative magic"), backgrounding, suggestion, and immersion. Sometimes various strategies were used in the same film.

${ }^{6}$ For example, The Magnificent Seven has the second-highest all-time number of viewers of any foreign film in Russia (Kudryavtsev). Of course, in this case it must have been due to some extent to its Russian-born star Yuliy Borisovich Briner (Yul Brenner). 
Although sympathy for speakers of other languages was expressed from the very beginning of the sample (Treasure of the Sierra Madre - 1948), antipathy and/or ridicule was likewise expressed (Red River - 1948, Winchester '73 - 1950). True protagonism, however, for non-native English speakers did progress over time, beginning with Mexican love interests in High Noon (1952), Giant (1956) and One-eyed Jacks (1961, which also included a dignified Mexican sidekick), continuing in secondary lead characters (again, Mexicans) in The Magnificent Seven (1960) and The Wild Bunch (1969), and flowering in critical, although technically supporting roles for Native Americans: Chief Dan George in Little Big Man (1970) and The Outlaw Josey Wales (1976). This trend however, should be regarded with caution, however, since during this same period the sole protagonist in a non-NFR-listed Western by an NFR-listed director, Anthony Mann's tragedy The Devil's Doorway (1950), was a Native American (albeit played in "redface" by Robert Taylor).

Although the revisionist trend has since continued and evolved after 1976 through high-profile Westerns such as Dances with Wolves (1990), Bandidas (2006), The Hateful Eight (2015), and The Revenant (2015) and could be expected to continue, it is not clear whether new or different language strategies, or even different power relations with English, have also developed. ${ }^{7}$ The spectrum of approaches to portraying foreign language found in this study may also apply to films in other genres, epochs or countries.

\footnotetext{
${ }^{7}$ However, that fact that in 2020, for the first time, a film in a language other than English has won the Academy Award for Best Picture (Bong Joon-ho's Parasite) could indicate a sea change in the prestige of foreign language in American cinema.
}

Cad. Trad., Florianópolis, v. 40, n 2, p. 282-321, mai-ago, 2020. 


\section{References}

\section{A. Corpus \\ Main corpus}

Altman, Robert. (Director). McCabe \& Mrs. Miller. Warner Bros. Pictures, 1971.

Boetticher, Budd. (Director). The Tall T. Columbia Pictures Corporation, 1957.

Brando, Marlon. (Director). One-Eyed Jacks. Paramount Pictures Corporation, 1961.

Brooks, Mel. (Director). Blazing Saddles. Warner Bros., 1974.

Daves, Delmer. (Director). 3:10 To Yuma. Columbia Pictures Corporation, 1957.

Eastwood, Clint. (Director). The Outlaw Josey Wales. Warner Bros. Pictures, 1976.

Ford, John. (Director). The Searchers. Warner Bros. Pictures, 1956.

Ford, John. (Director). The Man Who Shot Liberty Valance. Paramount Pictures Corporation, 1962.

Hawks, Howard. (Director). Red River. United Artists, 1948.

Hawks, Howard. (Director). Rio Bravo. Warner Bros. Pictures, 1959.

Hill, George Roy. (Director). Butch Cassidy and the Sundance Kid. Twentieth Century Fox Film Corp., 1969.

Huston, John. (Director). The Treasure of the Sierra Madre. Warner Bros. Pictures, 1948. 
Leone, Sergio. (Director). Once upon a Time in the West. European Institute of Film/Paramount Pictures Corporation, 1968.

Mann, Anthony. (Director). Winchester '73. Universal Pictures Co., 1950.

Peckinpah, Sam. (Director). Ride the High Country. Metro-Goldwyn-Mayer, 1962.

Peckinpah, Sam. (Director). The Wild Bunch. Warner Bros., 1969.

Penn, Arthur. (Director). Little Big Man. National General Pictures, 1970.

Ritt, Martin. (Director). Hud. Paramount Pictures Corporation, 1963.

Stevens, George. (Director). Giant. Warner Bros. Pictures, 1956.

Stevens, George. (Director). Shane. Paramount Pictures Corporation, 1953.

Sturges, John. (Director). The Magnificent Seven. MGM/UA, 1960.

Zinnemann, Fred. (Director). High Noon. United Artists, 1952.

\section{Other corpus}

Library of Congress/National Film Preservation Board: Brief Descriptions and Expanded Essays of National Film Registry Titles. Disponível em: https://www. loc.gov/programs/national-film-preservation-board/film-registry/descriptionsand-essays/. Accessed January 5, 2019.

Nugent, Frank. The Searchers - Revised Final Screenplay. Obtained from: Aellea Classic Movie Scripts. Disponível em: www.aellea.com/script/searchers.html. Accessed November 21, 2019. 


\section{B. Other References}

“AFI CATALOG OF FEATURE FILMS." American Film Institute[a]. Disponível em: www.catalog.afi.com/Search?searchField = Genre\&searchText=western\&sortT ype $=$ sortByRelevance. Accessed February 28, 2019.

“AFI's 10 TOP 10: The 10 Greatest Movies In 10 Categories." American Film Institute[b]. Disponível em: www.afi.com/afis-10-top-10/. Accessed February 28, 2019.

“AFI'S 100 YEARS...100 MOVIES - 10TH ANNIVERSARY EDITION." American Film Institute[c]. Disponível em: www.afi.com/afis-100-years-100movies-10th-anniversary-edition/. Accessed February 28, 2019.

Anderson, Benedict. Imagined Communities: Reflections on the Origin and Spread of Nationalism. Verso, 1983/2016.

Baxter, John. Stanley Kubrick: a Biography. HarperCollins, 1997.

Bourdieu, Pierre (a). Language and Symbolic Power. Trans. Gino Raymond and Matthew Adamson. Harvard University Press, 1991.

Bourdieu, Pierre (b). On Television. Trans. Priscilla Parkhurst Ferguson. The New Press, 1996/1998.

“Cahiers Du Cinema 100 Films.” The Moving Arts Film Journal. Disponível em: www.web.archive.org/web/20160726130550/http:/www.themovingarts.com/ greatest-films/cahiers-du-cinema-100-films/. Accessed February 28, 2019.

Carlson, Paul Howard; Crum, Tom. Myth Memory and Massacre: the Pease River Capture of Cynthia Ann Parker. Texas Tech University Press, 2010.

Cohen, Patricia. "Indian Tribes Go in Search of Their Lost Languages." The New York Times, The New York Times, 5 Apr. 2010. Disponível em: www. nytimes.com/2010/04/06/books/06language.html?mcubz $=0$. Accessed February $10,2019$. 
Crystal, David. English as a Global Language. Cambridge: Cambridge University Press, 2003.

D'ooge, Craig. "Mrs. Robinson Finds a Home Librarian of Congress Names 25 Films to Film Registry." Library of Congress Information Bulletin, 30 Dec. 1996. Disponível em: www.loc.gov/loc/lcib/9621/nfr.html. Accessed February 28, 2019.

Even-Zohar, Itamar. "Polysystem Theory." Poetics Today, vol. 11, no. 1, (1990): 3-26.

Frankel, Glenn. “'The Searchers' Was Influential Film in Its Day and Still Resonates Today." The Washington Post, WP Company, 4 July 2013. Available at: https://www.washingtonpost.com/lifestyle/style/the-searchers-was-influentialfilm-in-its-day-and-still-resonates-today/2013/07/04/8b6d5e48-dffb-11e2-b2d4ea6d8f477a01_story.html. Accessed February 28, 2019.

Hanes, Vanessa Lopes Lourenço. The language of translation in Brazil: written representations of oral discourse in Agatha Christie. PhD thesis, Universidade Federal de Santa Catarina, 2015, Available at: www.tede.ufsc.br/teses/ PGET0288-T.pdf.

Kudryavtsev, Sergey. "Зарубежные Фильмы в Советском Кинопрокате." [Foreign films in Soviet film distribution] Kinanet, 4 July 2006. Disponível em: www.kinanet.livejournal.com/13882.html. Accessed Februrary 28, 2019.

Libby, Bill. "The Old Wrangler Rides Again.”. Cosmopolitan, Mar. (1964): 13-21.

Redish, Laura, and Orrin Lewis. "Native American State Names.". Native Languages of the Americas, 2015. Disponível em: www.native-languages.org/ state-names.htm. Accessed February 10, 2019.

Swaan, Abram de. Words of the World: the Global Language System. Polity, 2001.

Toury, Gideon. Descriptive Translation Studies - and Beyond. Benjamins, 1995/2012.

Cad. Trad., Florianópolis, v. 40, n 2, p. 282-321, mai-ago, 2020. 
Venuti, Lawrence. The Translators Invisibility: a History of Translation. Routledge, 1995/2018.

Recebido em: 27/12/2019

Aceito em: 18/03/2020

Publicado em maio de 2020

William F. Hanes. E-mail: hanes.wf@gmail.com. ORCID: https://orcid. org/0000-0002-4611-0999. 